\title{
Clinical Manifestations of COVID-19 in Children at a Pediatric Tertiary Center in Turkey
}

\section{${ }^{1}$ Yalcin Kara, ${ }^{1}$ Mahmut Can Kizil, ${ }^{2}$ Ebru Kacmaz, ${ }^{2}$ Mehmet Ozgur Arslanoglu, ${ }^{2}$ Eylem Kiral, ${ }^{2}$ Gurkan Bozan, ${ }^{1}$ Omer Kilic, ${ }^{3}$ Sabiha Sahin, ${ }^{4}$ Tercan Us, ${ }^{4}$ Gul Durmaz, ${ }^{2}$ Ener Cagri Dinleyici}

${ }^{1}$ Eskisehir Osmangazi University Faculty of Medicine, Department of Pediatrics, Division of Pediatric Infectious Diseases, Eskișehir,Turkey

${ }^{2}$ Eskişehir Osmangazi University Faculty of Medicine, Department of Pediatrics, Division of Pediatric Intensive Care, Eskisehir, Turkey

${ }^{3}$ Eskișehir Osmangazi University Faculty of Medicine, Department of Pediatrics, Division of Pediatric Emergency Care, Eskișehir, Turkey

${ }^{4}$ Eskişehir Osmangazi University Faculty of Medicine, Department of Microbiology, Eskișehir, Turkey

Correspondence:

Yalçın KARA

Eskisehir Osmangazi University

Faculty of Medicine, Department of Pediatrics, Division of Pediatric Infectious Diseases, Eskişehir,Turkey e-mail: dryalcinkara@hotmail.com

\section{Abstract}

Limited studies have been published on practices and management of coronavirus disease-2019 (COVID-19) in children from the beginning of the pandemic. With this study, we aimed to share the clinical and epidemiological characteristics of infection in pediatric patients and our experiences. COVID-19 Polymerase Chain Reaction (PCR) test positive pediatric patients we followed up in our hospital between March to December 2020 were included in the study. The epidemiological, laboratory, radiological, and clinical data of the patients were analyzed retrospectively. During the study period, 246 test positive pediatric patients were admitted. The median age was 9 years ( 2 months- 17 years), girls accounted for $53,7 \%$, and $76(31 \%)$ patients were asymptomatic. The cough was the predominant symptom $(48 \%)$, followed by fever $(43 \%)$ and sore throat $(15 \%)$. There was a household contact in $199(81 \%)$ of all cases and $32(12 \%)$ patients had comorbidity and chronic illness. The most common laboratory findings; lymphopenia (26\%), eosinopenia (21\%), monocytosis (18\%), high C-reactive protein (20\%). Distribution according to case classes; asymptomatic $(32,2 \%)$, mild $(52,4 \%)$, moderate $(13,8 \%)$, severe $(1.2 \%)$, critical $(0.4 \%)$. Of all cases, $48(19.5 \%)$ were inpatients and $11(4.5 \%)$ were in intensive care. Chest tomography was performed in $25(10 \%)$ patients and $10(4 \%)$ were abnormal. As a treatment, $22(8 \%)$ patients received favipiravir, $1(0.4 \%)$ lopinavir-ritonavir, $16(\% 6)$ antibiotics, 4 (1.6\%) methylprednisolone and $3(1.2 \%)$ low molecular weight heparin. COVID-19 is often asymptomatic and mild in children, it may rarely have a severe course. More caution should be exercised in children under 1 year of age and patients with comorbidities. Keywords: COVID-19, child, pandemics

Özet

Pandeminin başlangıcından itibaren çocuklarda COVID-19 tanı, klinik bulguları ve yönetimi hakkında sınırlı sayıda çalıșma yayınlanmıştır. Bu çalışma ile çocuk hastalarda COVID-19 enfeksiyonun klinik ve epidemiyolojik özelliklerini ve deneyimlerimizi paylaşmayı amaçladık. Mart 2020 -Aralık 2020 tarihleri arasında hastanemizde takip ettiğimiz COVID-19 polimeraz zincir reaksiyon testi pozitif çocuk hastalar çalıșmaya dahil edildi. Hastaların epidemiyolojik, laboratuvar, radyolojik ve klinik verileri geriye dönük olarak incelendi. Çalışmaya 246 çocuk hasta kabul edildi. Hastaların, \%53'ü kızdı ve ortanca yaşı 9'du (2 ay-17 yıl) ve 76’sı (\%31) asemptomatikti. En sık semptomlar, öksürük (\%48), ateș (\%43) ve boğaz ağrısıydı (\%15). Olguların 199'unun (\%81) ailesinde temas öyküsü mevcuttu ve 32'sinin (\%12) kronik hastalığı vardı. En sık görülen laboratuvar bulguları; lenfopeni (\%26), eozinopeni (\%21), monositoz (\%18), yüksek C-reaktif protein (\%20) di. Vakaların \%32'si asemptomatik, \% 52'si hafif, \%14'ü orta, $\% 1,2$ 'si șiddetli (\%1.2), \%0,4'ü kritik sınıftaydı. Hastaların 48’i $(\% 19,5)$ hastaneye yatırıldı, 11’i (\%4,5) yoğun bakımda takip edildi. Hastaların 25 'ine (\%10) akciğer tomografisi çekildi ve 10 'unda (\%4) anaormal bulgular mevcuttu. Tedavi olarak 22 (\%8) hastaya favipiravir, $1(\% 0,4)$ lopinavir-ritonavir, $16(\% 6)$ antibiyotik, $4(\% 1,6)$ steroid ve $\% 3(1,2)$ düșük molekül ağırlıklı heparin verildi. COVID-19, çocuklarda sıklıkla asemptomatik ve hafif olmasına rağmen, nadiren şiddetli seyredebilir. Özellikle bir yaşın altındaki çocuklarda ve komorbiditesi olan hastalarda daha dikkatli olunmalıdır.

Anahtar Kelimeler: COVID-19, çocuk, pandemi 


\section{Introduction}

In December 2019, many atypical pneumonia cases were detected in Wuhan, China, and spread rapidly to the World (1). This epidemic has been linked to a new coronavirus called Severe Acute Respiratory SyndromeCoronavirus-2 (SARS-CoV-2) and coronavirus disease-2019 (COVID-19), respectively. On March 11, 2020, the World Health Organization (WHO) announced a COVID-19 Pandemic (2).

The first COVID-19 case in our country was reported on March 11, 2020. In phylogenetic analysis, SARS-CoV-2 is included in the beta coronavirus family with the largest positivepolar RNA genome. (3) Droplets are the most common way for respiratory secretions to transfer pathogens from person to person, with an average incubation period of 1-14 days. It causes symptoms ranging from mild upper respiratory tract symptoms to severe respiratory failure in adult patients. In the early days of the COVID-19 pandemic, there were very few pediatric patients and children were thought not to be susceptible to this infection. A 10-year-old boy living in Shenzhen, China, was reported as the first pediatric case of COVID-19 in the literature on January 20, 2020. (4) Pediatric cases continued to be reported from many centers afterward. The clinical and laboratory manifestations of COVID-19 in children differ from those in adults, and the disease had a mild form in children than in adults. (5). However, it has also been reported that COVID-19 can be severe, especially in children with underlying chronic diseases (6). Despite the numerous studies, the COVID-19 course in children has not been fully elucidated. This study was carried out to shed light on the epidemiology, laboratory, and clinical course of COVID-19 in pediatric patients.

\section{Materials and Methods}

Between March 2020 and December 2020, children with positive COVID-19 PCR test results were enrolled in this study at Eskişehir Osmangazi University Medical Faculty Hospital, Department of Pediatrics. The study was sent for approval to the Ministry of Health's COVID-19 Scientific Research
Assessment Commission and the Eskişehir Osmangazi University Faculty of Medicine Ethics Committee (decision number,161618). Children aged 0 to 18 years old were included in the study if their combined nasopharyngeal swab sample was positive for COVID-19 PCR (confirmed by our hospital's microbiology and genetic laboratory using the Bio-Speedy Double Gene test kit). The hospital automation system was used to access the details of these patients, and the research was performed retrospectively. Patients who were negative for COVID-19 PCR and whose COVID-19 PCR test was found to be positive in other health institutions were not included in the study. The diagnosis, treatment, and follow-up of the cases were arranged according to the Ministry of Health COVID19 Pediatric Patient Guide and the World Health Organization data. The data belong to cases; epidemiological and demographic data, age, gender, contact and transmission history, presence of accompanying chronic disease and risk factors, symptoms and signs, laboratory and radiological findings (hemogram, CRP, procalcitonin, erythrocyte sedimentation rate, AST, ALT, urea, creatinine, LDH, triglyceride, D-dimer, INR, ferritin, chest radiography, chest computed tomography), echocardiography findings, service, and intensive care admission history, disease severity (asymptomatic, mild, moderate, severe, critical), treatments (favipiravir, hydroxychloroquine, lopinavir, steroid, antibiotic, oxygen support), treatment duration, disease course, etc. were evaluated. The classification of the disease degree was classified according to the COVID-19 guidelines of the Ministry of Health and the classification made by Dong et al, which is accepted in the literature (6). Patients were divided into 5 groups as asymptomatic, mild, moderate, severe, and critical illness, according to the clinical, laboratory findings, radiological findings, oxygen, and intensive care needs of the patients.

\section{Statistical analysis}

Statistical analysis was performed using SPSS (Statistical Package for the Social Sciences) version 21.0 software. Numerical properties 
were compared with the Mann - Whitney U test, and the relationships between numerical properties were analyzed by correlation analysis. The compatibility of the variables to normal distribution was examined using the Kolmogorov-Smirnov / Shapiro-Wilk tests. Descriptive analysis for normally distributed variables; The mean, standard deviation, and the median (minimum-maximum) for nonnormally distributed variables were given. Categorical variables were expressed as "\%". $\mathrm{p}<0.05$ was considered statistically significant.

\section{Results}

Between March 2020 and December 2020, combined nasopharyngeal swab samples were taken from 2225 pediatric patients for suspicion of COVID-19 infection, and 246 $(10.2 \%)$ patients were found to be positive for COVID-19. In patients with positive COVID19 PCR test, 132 were girls (53.7\%). The median age was 9 years (min: 2 months, max: 17 years). The cases were divided into five age groups, with approximately half of the cases $(55 \%)$ being children over the age of ten. There was a household contact in 199
(81\%) of all cases. A total of 32 cases had comorbid diseases, with the most common being a chronic hematological disease in 6 patients, chronic kidney disease in 4 four patients, chronic lung disease in 3 patients, chronic heart disease in 2 patients, and obesity in 4 patients (Table-1). While 76 of all cases were asymptomatic, the most common symptom was cough $(48 \%)$, followed by fever $(43 \%)$, sore throat $(15 \%)$, shortness of breath (12\%), myalgia (11\%) (Table 1). Chest X-ray was taken in 66 patients and 6 of them had infiltration and consolidation. Lung tomography was performed in $25(10.2 \%)$ patients, $10(4.1 \%)$ patients had ground-glass opacity, consolidation, and infiltration. In four patients who were found to be normal on chest X-ray, ground-glass opacity and infiltration were found in lung tomography (Table-2). The most common laboratory findings; lymphopenia in 66 (26.8\%), eosinopenia in $53(21.5 \%)$, elevated CRP in $48(20 \%)$, monocytosis in $45(18.3 \%)$, leukopenia in $20(8.1 \%)$, leukocytosis in 15 (6.1\%) (Table 1). Elevated CRP, LDH, and ferritin levels were prominent in the inpatient group compared to outpatients (p: 0.01) (Table-2).

Table 1.Demographic and clinical features of patients with COVID-19

\begin{tabular}{lllll}
\hline Factors & $\begin{array}{l}\text { All patients } \\
(\mathbf{n : 2 4 6}(\mathbf{\%})\end{array}$ & $\begin{array}{l}\text { Outpatient } \\
(\mathbf{n : 1 9 8})(\mathbf{\%})\end{array}$ & $\begin{array}{l}\text { Inpatient } \\
(\mathbf{n : 4 8})(\mathbf{\%})\end{array}$ & $\mathbf{p}$ \\
\hline Sex & $132(54)$ & $108(81)$ & $24(19)$ & 0,342 \\
\hline Girl & $114(46)$ & $90(79)$ & $24(21)$ & \\
\hline Boy & $9,4(2$ month-17) & $9,7(2$ month-17) & $8,1(2$ month-16) & $\mathbf{0 , 0 0 6}$ \\
\hline Age (year) & $18(7)$ & $8(44)$ & $10(56)$ & \\
$<1$ & $53(21)$ & $44(83)$ & $9(17)$ & \\
$1-5$ & $37(15)$ & $32(87)$ & $5(13)$ & \\
$6-10$ & $77(31)$ & $61(79)$ & $16(21)$ & \\
$11-15$ & $61(24)$ & $53(87)$ & $8(13)$ & \\
\hline 15 & & & & $\mathbf{0 , 0 0 2}$ \\
\hline Symptoms & $76(31)$ & $76(100)$ & $0(0)$ & $\mathbf{0 , 0 0 1}$ \\
\hline Asymptomatic & $120(48)$ & $87(73)$ & $33(27)$ & 0,300 \\
\hline Cough & $107(43)$ & $64(60)$ & $43(40)$ & $\mathbf{0 , 0 0 1}$ \\
\hline Fever & $38(15)$ & $29(76)$ & $9(23)$ & $\mathbf{0 , 0 2 5}$ \\
\hline Sore throat & $30(12)$ & $10(33)$ & $20(67)$ & $\mathbf{0 , 0 0 1}$ \\
\hline Shortness of breath & $28(11)$ & $18(64)$ & $10(36)$ & $\mathbf{0 , 0 0 1}$ \\
\hline Myalgy & $12(5)$ & $3(25)$ & $9(75)$ & 0,192 \\
\hline Chest Pain & $9(3,7)$ & $1(11)$ & $8(89)$ & $\mathbf{0 , 4 1 1}$ \\
\hline Vomiting & $9(3,7)$ & $5(63)$ & $3(37)$ & $\mathbf{0 , 0 2 4}$ \\
\hline Headache & $7(2,9)$ & $5(71)$ & $2(29)$ & $<\mathbf{0 , 0 0 1}$ \\
\hline Diarrhea & $4(1,5)$ & $1(25)$ & $3(75)$ & $\mathbf{0 , 0 0 1}$ \\
\hline Abdominal pain & $5(2)$ & $0(0)$ & $5(100)$ & \\
\hline Neurological sign & & $2(67)$ & $1(33)$ & \\
\hline Accompanying diseases & $3(1,2)$ & & & \\
\hline Lung diseases & & & & \\
\hline
\end{tabular}




\begin{tabular}{|c|c|c|c|c|}
\hline Congenital heart Disease & $2(0,8)$ & $2(100)$ & $0(0)$ & \\
\hline Renal disease & $4(1,6)$ & $4(100)$ & $0(0)$ & \\
\hline Romatological diseases & $3(1,2)$ & $2(67)$ & $1(33)$ & \\
\hline Hemato-Oncological diseases & $6(2,4)$ & $3(50)$ & $3(50)$ & \\
\hline Gastrointestinal diseases & $5(2)$ & $4(80)$ & $1(20)$ & \\
\hline Neurological disease & $2(0,8)$ & $0(0)$ & $2(100)$ & \\
\hline Immun deficiency & $2(0,8)$ & $2(100)$ & $0(0)$ & \\
\hline Tip-1 DM & $1(0,4)$ & $0(0)$ & $1(100)$ & \\
\hline Obesity & $4(1,6)$ & $0(0)$ & $4(100)$ & \\
\hline \multicolumn{5}{|l|}{ History of Contact } \\
\hline Housohold contact & $199(81)$ & $163(82)$ & $36(18)$ & 0,300 \\
\hline School contact & $6(4)$ & $5(83)$ & $1(17)$ & \\
\hline No contact & $39(15)$ & $27(71)$ & $11(29)$ & \\
\hline
\end{tabular}

Table 2. Laboratory and radiolocigal findings of patients with COVID-19

\begin{tabular}{|c|c|c|c|c|}
\hline Laboratory & $\begin{array}{l}\text { All patients } \\
(\mathrm{n}: 246)(\%)\end{array}$ & $\begin{array}{l}\text { Outpatients } \\
(\mathrm{n}: 198)(\%)\end{array}$ & $\begin{array}{l}\text { Inpatients } \\
(\mathrm{n}: 48)(\%)\end{array}$ & $\mathbf{P}$ \\
\hline Leucocyt & $8162(1310-62910)$ & $1550(1550-17400)$ & $9254(1310-62910)$ & \\
\hline Leucocytosis & $15(14,7)$ & $6(5,9)$ & $9(8,8)$ & 0,504 \\
\hline Leucopenia & $20(19)$ & $11(10)$ & $9(9)$ & 0,500 \\
\hline Lymphocyte & $3119(400-60420)$ & $2358(400-7420)$ & $4140(410-60720)$ & \\
\hline Lymphopenia & $66(64,7)$ & $38(37,3)$ & $28(27,5)$ & 0,504 \\
\hline Eosinophils & $134(0-4700)$ & $98(0-800)$ & $182(0-4700)$ & \\
\hline Eosinopenia & $53(52)$ & $27(26,5)$ & $26(25,5)$ & 0,146 \\
\hline Monocytes & $815(70-2730)$ & $798(70-1960)$ & $836(150-2730)$ & \\
\hline Monocytosis & $45(43,7)$ & $23(22,3)$ & $22(21,4)$ & 0,180 \\
\hline CRP & $13(1-181)$ & $10(1-119)$ & $16(1-181)$ & \\
\hline Crp $\uparrow$ & $45(48,4)$ & $23(24,7)$ & $22(23,7)$ & 0,184 \\
\hline D-dimer & $1,2(0,1-26)$ & $0,6(0,1-6)$ & $1,7(0,2-26)$ & \\
\hline D-dimer $\uparrow$ & $27(40,3)$ & $9(13,4)$ & $18(26,9)$ & 0,018 \\
\hline LDH & $284(125-1500)$ & $257(125-780)$ & $324(132-1500)$ & \\
\hline $\mathrm{LDH} \uparrow$ & $29(34,1)$ & $14(16,5)$ & $15(17,6)$ & 0,117 \\
\hline Ferritin & $118(4-857)$ & $68(4-344)$ & $180(28-857)$ & \\
\hline Ferritin $\uparrow$ & $7(13,7)$ & $1(2)$ & $6(11,8)$ & $\mathbf{0 , 0 2 7}$ \\
\hline ProBNP & $251(8-3671)$ & $86(10-570)$ & $8(89)$ & \\
\hline ProBNP $\uparrow$ & $5(20)$ & $2(8)$ & $3(12)$ & 0,230 \\
\hline Chest X-ray & $66(26,8)$ & $38(15,4)$ & $28(11,4)$ & 0,001 \\
\hline Normal & $60(24,4)$ & $36(14,6)$ & $24(9,9)$ & \\
\hline Consolidation+Infiltration & $6(2,4)$ & $2(0,8)$ & $4(1,6)$ & \\
\hline Chest tomography & $25(10)$ & $13(5,3)$ & $12(4,8)$ & 0,001 \\
\hline Normal & $15(6,1)$ & $9(3,7)$ & $6(2,4)$ & \\
\hline Abnormal & $10(4,1)$ & $4(1,6)$ & $6(2,4)$ & \\
\hline \multicolumn{5}{|l|}{ Treatment } \\
\hline Supportive & $221(89)$ & $188(76)$ & $33(13)$ & 0,001 \\
\hline Favipiravir & $22(8,9)$ & $8(3,3)$ & $14(5,7)$ & 0,001 \\
\hline Lopinavir-ritonovir & $1(0,4)$ & $1(0)$ & $1(0,4)$ & 0,195 \\
\hline Steroid & $6(2,4)$ & $2(0,8)$ & $4(1,6)$ & 0,004 \\
\hline LMWH & $3(1,2)$ & $0(0)$ & $3(1,2)$ & 0,001 \\
\hline Antibiotics & $16(6,5)$ & $2(0,8)$ & $14(5,7)$ & 0,001 \\
\hline Ventilation support & & & & 0,001 \\
\hline Noninvasive ventilation & $4(1,6)$ & $0(0)$ & $4(100)$ & \\
\hline Invasive ventilation & $1(0,4)$ & $0(0)$ & $1(18)$ & \\
\hline
\end{tabular}

Distribution according to case classes; $1(0.4 \%)$ patient were observed. Of all cases Asymptomatic $79(32,2 \%)$, mild $129(52,4 \%), 198$ were followed up as outpatients, 48 as moderate $34(13.8 \%)$, severe $3(1.2 \%)$, critical inpatients, and 11 as intensive care patients. 
While the morbidity rate was very low in our study, there was no mortality. The mean length of stay in the hospital was 6.9 days (Table-3). Patients who received favipiravir 22(8\%), lopinavir-ritonavir 1(0.4\%), antibiotics $16(6.5 \%)$, methylprednisolone
$4(1.6 \%)$, and low molecular weight heparin $3(1.2 \%)$. Thirty-nine patients received oxygen therapy via mask and nasal cannula, four received noninvasive ventilation, and one received invasive ventilation (Table-3).

Table 3. Treatment and clinical classification of patients with COVID-19

\begin{tabular}{|c|c|c|c|c|c|c|}
\hline & Asymptomatic & Mild & Moderate & Severe-Critic & Total & $\mathbf{P}$ \\
\hline Age & & & & & & 0,008 \\
\hline$<1$ age & $3(1,2)$ & $9(3,7)$ & $5(2)$ & $1(0,4)$ & $18(7,3)$ & \\
\hline $2-5$ age & $16(6,5)$ & $33(13,4)$ & $4(1,6)$ & $0(0)$ & $53(21,5)$ & \\
\hline $6-10$ age & $10(4,1)$ & $24(9,8)$ & $3(1,2)$ & $0(0)$ & $37(15)$ & \\
\hline $11-15$ age & $28(11,4)$ & $37(15)$ & $9(3,7)$ & $3(1,2)$ & $77(31,3)$ & \\
\hline$>15$ age & $22(8,9)$ & $26(10,6)$ & $13(5,3)$ & $0(0)$ & $61(24,8)$ & \\
\hline Total & $79(32,2)$ & $129(52,4)$ & $34(13,8)$ & $4(1,6)$ & $246(100)$ & \\
\hline Treatment & & & & & & 0,001 \\
\hline Favipiravir & $0(0)$ & $1(0,4)$ & $17(6,9)$ & $4(1,6)$ & $22(8,9)$ & \\
\hline Lopinavir-Ritonovir & $0(0)$ & $0(0)$ & $0(0)$ & $1(0,4)$ & $1(0,4)$ & \\
\hline Steroid & $0(0)$ & $0(0)$ & $3(1,2)$ & $3(1,2)$ & $6(2,4)$ & \\
\hline DMAH & $0(0)$ & $0(0)$ & $0(0)$ & $3(1,2)$ & $3(1,2)$ & \\
\hline Antibiotics & $0(0)$ & $5(2)$ & $7(2,8)$ & $4(1,6)$ & $16(6,5)$ & \\
\hline Oxigen support & & & & & & $\mathbf{0 , 0 0 1}$ \\
\hline $\begin{array}{l}\text { Noninvazive } \\
\text { ventilation }\end{array}$ & $0(0)$ & $0(0)$ & $0(0)$ & $4(1,6)$ & $4(1,6)$ & \\
\hline İnvazive ventilation & $0(0)$ & $0(0)$ & $0(0)$ & $1(0,4)$ & $1(0,4)$ & \\
\hline
\end{tabular}

\section{Discussion}

After the World Health Organization declared COVID-19 a pandemic in March 2020, the entire world has struggled to control and treat this pandemic. While data on pediatric patients was limited at the start of the pandemic, data were updated on a daily basis with the participation of all countries and centers. In this study, we looked at the epidemiological, laboratory, and clinical data of 246 COVID-19 PCR positive pediatric patients who were followed up on at our center. Although COVID-19 is seen in children of all ages, it progresses with milder clinical findings than in adults $(6,7)$. In our study, appropriate to the literature, 79 (32,2\%) of the cases were asymptomatic and 129 $(52,4 \%)$ had mild symptoms. Observation of children who have milder symptoms than adults; Children with lower expression of ACE-2 cell receptors and S-proteins involved in coronavirus pathology, as well as a more active natural immune system as a result of previous viral infections, are thought to have a better response to COVID-19 (8-10). In our study, 53,7 percent of COVID-19 -PCR positive pediatric patients were girls, with median age of 9 years. While the majority of cases were over ten years old, there were only 18 cases that were under than 1-year-old. While the number of cases increased with age, the rate of hospitalization was higher in children under the age of one year. According to Dong et al. boys are more affected than girls. According to the same study, COVID19 has a more severe course in those under the age of one year and those with concurrent chronic diseases (6). In our study, however, there was no significant difference between boys and girls in terms of both disease onset and progression. The rate of hospitalization was higher in children under the age of one year. This can be explained by the higher number of hospitalizations (unrelated to clinical severity) for follow-up and surveillance in children under the age of one year. In our study, 32 of the cases also had chronic diseases. The most common symptoms of COVID-19 in children in studies 
with large case numbers were fever, cough, shortness of breath, chest pain, sore throat, but other system findings such as headache, diarrhea, vomiting, and abdominal pain have also been shown to cause less frequently $(6$, 11-13). Similar to the literature, the most common symptoms at presentation in our study were cough, fever, sore throat, and shortness of breath. Patients who presented with dyspnea, chest pain, or neurological findings were more likely to be hospitalized. The majority of pediatric cases were infected through household contacts. A study found that this rate was 94 percent (7). There was a history of household contact in $81 \%$ of our cases. According to clinical and laboratory findings, COVID-19 positive cases were classified as asymptomatic, mild, moderate, severe, or critical in the study by Dong et al (6). 4.4 percent of the cases were asymptomatic, 50.9 percent were mild, 38.8 percent were moderate, 52 percent were severe, and 0.6 percent were critical. Similarly, in our study, the distribution of cases was as follows: asymptomatic $32,2 \%$, mild $52,4 \%$, moderate $13,8 \%$, severe $1,2 \%$, and critical $0,4 \%$. The number of asymptomatic cases was higher than expected based on the literature. This can be explained by the early screening of parent-positive family members. The most frequently reported laboratory findings were lymphopenia, elevated CRP, elevated LDH, elevated D-dimer, and normal procalcitonin levels (14-16). The most common laboratory findings in our study included lymphopenia, eosinopenia, monocytosis, and elevated CRP levels. D-dimer and ferritin levels were higher in hospitalized patients and moderate-tosevere patients.

Although COVID-19 causes some changes in the lung, such as consolidation, infiltration, and ground-glass opacity, chest radiography may be normal in the early stages of the disease, lung tomography is more sensitive. However, radiation exposure from tomography in childhood should be considered (17-18). Chest radiography was performed on 66 patients in our study, and lung tomography was performed on 25 patients. Consolidation, infiltration, and ground-glass opacity were found in ten of the twenty-five patients who underwent lung tomography. The frequency of lung tomography was lower than in the literature, and in four patients with normal chest radiography, a ground-glass opacity and infiltration were detected in lung tomography.

There is no established common treatment protocol for COVID-19 in pediatric patients. Supportive therapies, antiviral treatments, antibiotic therapy, oxygen support, steroid low molecular weight heparin, intravenous immunoglobulin, remdesivir, tocilizumab, and plasma therapy are all used (19-27). In our study, 22 patients received favipiravir, one patient received lopinavir-ritonavir, and three patients received low molecular weight heparin treatment. In none of our patients did we use hydroxychloroquine or oseltamivir treatment.Four patients received noninvasive ventilation, while one received invasive ventilation support. Favipiravir is typically used in moderate-to-severe and hospitalized patients, whereas low molecular weight heparin and steroids are typically used in severe and critical cases.

Our study had some limitations, including the use of observational data from a single center with a small sample size. There were only four serious and critical patients in our study. As a result, the small sample size may have prevented some analyses from reaching definitive conclusions. Despite these limitations, this study is important because it is one of the few reports on the characteristics of confirmed pediatric COVID-19 cases in Turkey. The study provides valuable data on pediatric cases because COVID-19 is a novel disease with limited data, particularly in the pediatric population.

As a result; Although COVID-19 is often asymptomatic and mild in children, it should be kept in mind that it can be severe and critical. In children under 1 year of age and patients with comorbidities, more care should be taken in the follow-up of the disease. The vast majority of pediatric patients are infected indoors, so children from families with positive parents should be closely monitored in terms of symptoms and signs. Larger and multi-center clinical studies are needed for the follow-up and treatment of COVID-19 in children. 


\section{REFERENCES}

1. Li Q, Guan X, Wu P, et al. Early Transmission Dynamics in Wuhan, China, of Novel Coronavirus-Infected Pneumonia. New Engl J Med 2020;382:1199-207.

2. World Health Organization. Coronavirus disease 2019 (COVID-19) situation report 73.Geneva,Switzerland:WorldHealthOrganizat ion;2020.

3. Lu R, Zhao X, Li J, et al. Genomic characterization and epidemiology of 2019 novel Coronavirus: implications for virus origins and receptor binding. Lancet. 2020; 22;395:565-74.

4. Chan JF, Yuan S, Kok KH et al. A familial cluster of pneumonia associated with the 2019 novel coronavirus indicating person-to-person transmission: a study of a family cluster. Lancet. 2020;395:514-23.

5. Fang F, Luo XP. Facing the pandemic of 2019 novel coronavirus infections: the pediatric perspectives. Zhonghua $\mathrm{Er} \mathrm{Ke} \mathrm{Za}$ Zhi. 2020;58:81-5.

6. Dong Y, Mo X, Hu Y, et al. Epidemiological characteristics of 2143 pediatric patients with 2019 coronavirus disease in China. Pediatrics 2020. Epub March 16, 2020.

7. CDC COVID-19 Response Team. Coronavirus disease 2019 in children-United States, February 12-April 2, 2020. MMWR 2020;69:422-6.

8. Xie X, Chen J, Wang X, et al. Age- and gender-related difference of ACE2 expression in rat lung. Life Sci 2006; 78: 2166-71.

9. Lee PI, Hu YL, Chen PY, et al. Are children less susceptible to COVID-19? J Microbiol Immunol Infect 2020; 53: 371-2.

10. Ludvigsson JF. A systematic review of COVID-19 in children shows milder cases and a better prognosis than adults. Acta Paediatr 2020.

11. Parri N, Lenge M, Buonsenso D; Coronavirus Infection in Pediatric Emergency Departments (CONFIDENCE) Research Group. Children with Covid-19 in Pediatric Emergency Departments in Italy. $N$ Engl $J$ Med. 2020;383:187-190.

12. Robbins E, Ilahi Z, Roth P. Febrile Infant: COVID-19 in Addition to the Usual Suspects. Pediatr Infect Dis J 2020; 39.

13. Zheng F, Liao C, Fan QH, et al. Clinical Characteristics of Children with Coronavirus Disease 2019 in Hubei, China. Curr Med Sci 2020; 40: 275-80.

14. Chen N, Zhou M, Dong $X$, et al. Epidemiological and clinical characteristics of 99 cases of 2019 novel coronavirus pneumonia in Wuhan, China: a descriptive study. Lancet 2020; 395: 507-13.

15. Henry BM, de Oliveira MHS, Benoit S, Plebani M, Lippi G. Hematologic, biochemical and immune biomarker abnormalities associated with severe illness and mortality in coronavirus disease 2019 (COVID-19): a meta-analysis. Clin Chem Lab Med. 2020 ;58:1021-28.

16. Henry BM, Lippi G, Plebani M. Laboratory abnormalities in children with novel coronavirus disease 2019. Clin Chem Lab Med 2020; 58: 1135-8.

17. Xia W, Shao J, Guo Y, et al. Clinical and CT features in pediatric patients with COVID-19 infection: Different points from adults. Pediatr Pulmonol 2020; 55: 1169-74.

18. Ai T, Yang Z, Hou H, Zhan C, Chen C, Lv W, Tao Q, Sun Z, Xia L. Correlation of Chest CT and RT-PCR Testing for Coronavirus Disease 2019 (COVID-19) in China: A Report of 1014 Cases. Radiology. 2020 ;296:E32-E40.

19. Yang P, Liu P, Li D, et al. Corona Virus Disease 2019, a growing threat to children?. J Infect 2020; 80: P671-93. 35.

20. T.C. Sağlık Bakanlığı Halk Sağlığı Genel Müdürlüğü. COVID-19 (SARS-CoV-2 enfeksiyonu) COVID-19_Rehberi-612.04.2020.

21. Chen C, Huang J, Cheng Z, et al. Favipiravir versus arbidol for COVID-19: a randomized clinical trial. MedRxiv. 2020 April 15. doi: https://doi.org/10.1101/2020.03.17.2003 7432.

22. Cao B, Wang Y, Wen D, et al. A trial of lopinavir-ritonavir in adults hospitalized with severe Covid-19. N Engl J Med 2020;382: 1787-99.

23. Russell CD, Millar JE, Baillie JK. Clinical evidence does not support corticosteroid treatment for 2019-nCoV lung injury. The Lancet 2020; 395: 473-5.

24. Bhimraj A, Morgan RL, Shumaker AH, et al. Infectious Diseases Society of America Guidelines on the Treatment and Management of Patients with COVID-19. Clin Infect Dis. 2020.

25. Mehta P, McAuley DF, Brown $M$, et al. COVID-19: consider cytokine storm syndromes and immunosuppression. Lancet 2020; 395: 1033-4.

26. Shen C, Wang Z, Zhao F, et al. Treatment of 5 Critically Ill Patients With COVID-19 With Convalescent Plasma. JAMA 2020; 323: 1582 9. 